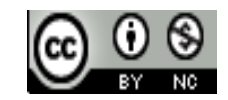

Journal of Education, Teaching and Learning is licensed under A Creative Commons Attribution-Non Commercial 4.0 International License.

\title{
The Effectiveness Of Using Photograph In Teaching Writing
}

\author{
Megawati ${ }^{1)}$, Syarif Agussaid Alkadrie ${ }^{2)}$ \\ 1) STIE,Pontianak \\ E-mail: cutmegawati44@yahoo.com \\ 2) STIE, Pontianak \\ E-mail:agusalkadrie@yahoo.com
}

\begin{abstract}
This research entitled: "The Effectiveness of Using Photograph in Teaching Writing" is intended to find out whether there is significantly different in writing ability between the experimental group and the control group.

This research employed experimental design. The participants of the study were the tenth-grade students at SMAN 1 Karau Kuala in the academic year 2013/2014. Two classes were used in this research. There were X-C as the Experimental group and X-D as the control group. The research instrument used was a writing test in the form of essay test. The data in this research were mainly gathered through the use of pre-test and post-test. The data were analyzed by measuring t-test and SPSS program to calculate the t-value from the score. The finding of the research shows that there is a significant difference between teaching writing by using photograph and teaching writing without using photograph. After the treatments, the mean is 75.43 the standard deviation is 9.370 the $\mathrm{df}$ is 44 , and the significance is 0.00 . If the significance is smaller than 0.05 , it means there is a significant difference between teaching writing by using photograph and teaching writing without using photograph.
\end{abstract}

Keywords: Photograph, Writing, Recount Text, Experimental Research

\section{INTRODUCTION}

\section{A. Background}

Writing is the expression of language in the form of letters; symbol and words; through writing someone can share their knowledge, conveying idea, feeling and intention to other people. Writing as a part of the language skills, besides listening, speaking and reading must be taught maximally by the teacher to the student. Writing is also one of communication media. Writing is very important as it can help us to have a good socialization, express our idea, feeling, and our opinion so that we can have a good interaction with our society (Byrne, 1991: 24). According to Gebhardt and Rodrigues (2000: 1) writing is one of the most important things you do in college. According to Ramelan (1994: 9) writing is very important as a part of man culture because it can be used to preserve thought idea and also speech sounds.

Although, writing is very important, it is a difficult subject especially for the students. Because writing is a complex activity since it requires students' comprehensive abilities such as mastering grammar, vocabulary, and punctuation. Besides, to write well, the students expected to be able to present their ideas in the written form as writing is a means of communication. However, some think that writing was not only delivering ideas to others but also using a sheer energy to complete the writing process itself: thinking the ideas, preparing the outline, transferring the outline into draft, revising the draft, and finally proofreading the draft to prepare for the final outcome. According to Heaton (1987: 134) writing skill is more complex and difficult to teach, requiring, and mastering not only of grammatical and rhetorical devices but also conceptual and judgment elements, because of the difficulties of writing, some efforts have been done to solve the problem. The main objective is to make the writing become easier to learn for the students. Fergenson and Nickerson (1998: 7) state that writing is a skill that is acquired through study. Writing is one of English skills that should be taught integrated, but it is regarded as the most difficult language skill to learn for learners. It is often perceived as the most difficult language skill since it requires a higher level of productive language control than the other skills. In fact, the students were not capable to make a good writing. The reason that they did not make a good writing was caused by poor in vocabulary, difficulty in generating their idea, poor in grammar, and so on. Besides that they also have difficulty in how to compose sentences, the students are lack of vocabulary and also lack of grammar acquisition. As a result, the students have no motivation to write, and writing becomes uninteresting and hard activity for them. 
The problems above also faced by the tenth-grade students of Senior High School in Kalimantan Tengah. Based on the preliminary observation conducted, the students complained that writing was a difficult subject. It was because they were so difficult to share the ideas from their brain and also not interested enough to learn English especially in writing recount text subject. Most of them found difficulties in developing paragraph and finding appropriate vocabulary and they felt bored. Besides that, the teacher seldom taught writing to the students through writing process. She just explained the patterns and gave the example of the text, and then she asked the students to write a certain topic without any guidance. The students only get the materials from texts books and exercise books. The teacher still teaches the students with routine activities without realizing that it would make the students bored and lost their attention to the teaching and learning process. This is stated by Brown (2006: 48) routine activities in learning can make the students bored. As the result, their motivation and participation in learning will decrease. These cases made their writing scores were low. There was no variation in the teaching writing.

Anyhow, the problems should be solved by trying to find another strategy for teaching writing in order to make an effective learning writing process. By applying the techniques, the teacher can encourage the students to participate in the classroom activities. The teacher should be able to encourage the students to express their ideas into good writing. The teacher gives opportunities to the students to write their ideas without being afraid of making mistake. It can be done by introducing topics and a good writing process. It is supposed to help students comprehend writing material well, so it can increase the students' writing score. Meanwhile, the main objective is to make the writing become easier to learn for the students. So photographs as new media for the tenth-grade students of Senior High School Kalimantan Tengah was interested to apply, because photographs can be used to guide the students to get the ideas in writing especially in recount text.

Photograph is one of the visual aids that will be effective and attractive in teaching writing recount text because photograph usually capture past events and photograph surely can help students remember details about people, places and events. Additionally, Wright (1989: 29) states that pictures are very important in helping students to retell experiences or understand something since they can represent place, object, people, etc.

Photograph or real picture is one of visual aids that can be used in teaching and learning English. It created the situation for learning classes and interesting. Kreidler (1968: 41) states that the ultimate of writing is to give the students the opportunity to express their own ideas clearly, using pattern they have learned. Photograph can also be used as teaching media. Many teachers used photograph as media enthusiastically think that photograph can lead to numerous creativities if used by teachers and students (Brown, 2006: 149).

Based on the usefulness of the photograph, photograph was choosing to teach writing recount text. Besides that there is relationship between writing recount text and the useful of photograph, in writing recount text "telling about what happened" and "past experience". Photograph is one of visual media to remember about past experience and about what happened in the past. There is a significant relationship between writing recount text and the useful of using photograph, recount text is one of the story genres. The purpose is to reconstruct past experiences by retelling events and incidents in the order in which they have occurred. Photograph as one of visual media types can improve fluency of understanding through elaboration of structure or organization and enhance retention (Azhar, 2009: 91). By such improvement writing recount text are consequently supported by enhanced retention and elaborated structure of mind. Moreover, recount text retells past events or activities in line with photograph that can capture interconnected images of objects and setting within.

Because of the explanations above, it was motivated to conduct an experimental research; the objective is to find out the effectiveness of using photographs in helping the students in writing ability, especially in writing recount text.

\section{B. Formulation of the Problem}

Is there a significant difference of writing ability between the students taught by using photographs and those taught by using conventional media of the experiment group and the control group of the students of Senior High School in Kalimantan Tengah?

\section{Objective of the Research}

Based on the formulation above, the research is aimed to find out there is a significant difference of writing ability between the students taught by using photographs and those who taught by using conventional media of the experiment group and the control group of the students of Senior High School in Kalimantan Tengah.

\section{REVIEW OF RELATED THEORIES}

\section{A. Definition of Writing}

There are some definitions of writing that are taken from resources, according to Hornby (2000: 1383) writing is the activity or occupation of writing for example books, stories and articles.

Dullay (1982: 226) gives statement that writing is only mode in which both linguistics manipulation task and communication task have been given. In the other words, Endang (2010: 151) states that writing as a process are oriented towards work in progress and the development of new skills, rather than merely evaluative task, the classroom practices, therefore, will vary from each other. Nunan (2003: 88) defines that writing is the process of thinking to invent ideas, thinking about how to express into good writing, and arranging the ideas into statement and paragraph clearly.

Based on the statements, it can be concluded that writing is 
an active. Production is more clearly, writing is an act or process to produce some information in their mind that should be expressed into writing form. Writing will be the best if the students guide on the rules defined. It usually refers to contents, organization, grammatical, usage and mechanics, sentence structure, mastery on vocabulary and so on.

\section{B. Definition of Writing}

According to Rudi (2005: 6) recount text is one of kind of story genre, recount tells somebody about something, especially something informing or entertaining. Anderson (2003: 48) gives statement that a recount is speaking or writing about past events or a piece of text that retells past events, usually in the order which they happened. Recount text means the form of the text telling about someone experience in the past, there for the experience of the readers themselves, such as their adventure and their day's activities. Recount text means telling about oneself adventures or the day's activities (Echols, 2008: 471). Recount text is one of text genres that are presented in genre-based-approach. Recount text refers to text which retells chronological activities in the past usually from writer's personal interpretation (Emilia, 2010: 106).

According to Hyland (2009: 29) recount is a kind of genre that has social function to retell event for the purpose of informing or entertaining. The tense that used in recount text is past tense. Social purpose of recount is to reconstruct past experiences by retelling events in original sequence. We can look at the sample of recount in personal letters, police report, insurance claims, and incident reports.

\section{B. Photographs}

Photograph is a picture made by using a camera, in which an image is focused on to light sensitive material, and then made visible and permanent by chemical treatment or store digitally (Oxford Dictionary, 2008: 329).

Photograph is one of type of picture; Ann (2001: 930) states that picture is defined as visual representation of person, object, or scene, as a painting, drawing, or photograph. According to Harmer (2007: 134) pictures can be flash cards, large wall pictures, photographs, or illustration.

Photograph is used as media to teach the lesson material. Photographs are extremely useful for a variety of communication activity, such as describe and draw activities.

\section{Photographs as Aids}

Photographs are often used to remind people of a real experience or to suggest such as experience to them. For example, most of families have photograph album to remind themselves of happy time in the past. Gerlach and Elly (2003: 273) describe four categories of still picture which can be found in film strips slide and overhead transparencies. Still might be drawn printed or photographically process, abstract at the various in size and color. The most common opaque still pictures are photographic prints but cartoon a wall painting, sketches and maps widely used.
Photograph or real picture is one of visual aids that can be used in teaching and learning English. It creates the situation for learning classes and interesting. Kreidler (1968: 41) stated that the ultimate of writing is to give the students the opportunity to express their own ideas clearly, using pattern they have learned.

\section{E. Teaching Writing Using Photograph As Media}

There are several methods in teaching and learning writing. Photograph is one of ways to explain a real situation. Teacher is the most important factor in teaching and learning process, especially in English subject. The teacher must be had an ability to make an interesting class. Photograph is one of the teaching media that can make the students enjoy the lesson. Among the teaching media, photographs are the common media to be used. There are two kinds of photographs that are used in teaching and learning process Yuswotowo (1992: 14), they are: the original picture and the picture of illustration. The original picture shows the concrete shapes of the object or person related to the topic being discussed. The pictures of illustration on the other hand are made in order to display a situation or an object needed for teaching activities such as illustration of a conversation between mother and father in a dining room.

Finocchiaro (1989: 164) also suggests that every classroom should contain a file of pictures which can be used to give interesting, meaningful practice of a foreign language. The file should contain three kinds of pictures: (1) pictures of individual person and of individual object, (2) pictures of situation in which persons are doing something with object and in which the relationship of subjects or people can be seen, and (3) a series of pictures on one chart.

Photograph can also be used as teaching media. Many teachers used photograph as media enthusiastically think that photograph can lead to numerous creativities if used by teachers and students (Brown, 2006: 149). The creativity can extend started from taking the picture to the way the photographs are used. Nowadays, photograph is relatively economical, if it is used as teaching media in classroom. Camera in the cellular can also be effectively used so that photograph is easily gained by students.

The use of written text media is very dominating. The Students in dealing with written text sometimes feel boredom and get stuck to write. Variation of media is useful in dealing with such problem because the use of media in class can raise new willingness and interest, motivation and stimulus to learn, and even have psychological effect towards student (Azhar, 2009: 15).

Teacher can stimulate their students by instructing them to take a good picture by themselves (Brown, 2006: 150). My Own Best Picture created by the teacher in this study is one of example of such effort. My Own Best Picture really jives with the recount text characteristics which compose about past events. My Own Best Picture is sequential pictures taken from students' experience. My Own Best Picture is like multi screen stills which showed development of events chronologically. Taking picture by themselves (students) can 
be very exciting and inevitably improves their visual literacy (Brown, 2006: 150).

By photograph, learners can show people, places, and things from areas outside their own experiences (Gerlach and Elly, 2003: 273). Photograph as one type of picture, can present social context in classroom in which people and places are put together in certain relation creating events that can trigger students' imagination. Hopefully, after visual literary is boosted by the present of photograph, students can also improve their literacy, especially writing recount context. Photograph that can show areas outside one experience enable learners to be able to explain anything that they can perceive from the photograph, even something new for them. Photograph visual detail makes it possible to study subjects which would otherwise be impossible (Gerlach and Elly, 2003: 277).

Some students, when they try to write events they already experienced, found difficulty to gain exact memory about that. Furthermore, it will be more difficult to retrieve the details of object they would talk about. To cope with such problem, visual media like photograph can be a solution because visual media can elaborate well structure or organization of things and enhance retention (Azhar, 2009: 91).

Based on the review of the existing literature on the advantages of using photograph in teaching of writing, the present study was carried out to investigate how a photographaided learning strategy improves the writing ability of senior high school students in Indonesia.

\section{RESEARCH METHOD}

\section{A. Research Design}

This research was quasi-experimental design. Quasiexperimental design was not based on random assignment of subjects to experiment and control groups. Related to the research, nonrandomized control group pre-test post-test design was used. According to Wido (2006: 215) quasiexperimental design is not based on random assignment of subjects to experiment and control groups. This design was used because of the school situation, schedules cannot be disrupted. In such a case, it was necessary to use groups as they were already organized into classes or other intact groups.

Quasi-experiment involved an experiment group and a control group both given a pre-test and a post-test. Pre-test was given to both of the groups to measure the students' writing ability before the treatment was given. The treatment was only given to experiment group. Then post-test was given to both of the groups to measure the students' writing ability after the treatment was given.

The treatments consisted of six meetings. Photograph was only used to teach the experiment group. The material that was used for both of the groups was the same. According to Creswell (2008: 242) the research design can be illustrated in the table below:
TABLE I

THE RESEARCH DESIGN

\begin{tabular}{cccc}
\hline Groups & Pre-test & Treatment & Post-test \\
\hline $\mathrm{E}$ & $\mathrm{O}_{1}$ & $\mathrm{X}$ & $\mathrm{O}_{2}$ \\
$\mathrm{C}$ & $\mathrm{O}_{1}$ & $\mathrm{Y}$ & $\mathrm{O}_{2}$
\end{tabular}

Where:

$\mathrm{O}_{1}$ : Pre-test of experiment group

$\mathrm{O}_{2}$ : Post-test of experiment group

$\mathrm{O}_{1}$ : Pre-test of control group

$\mathrm{O}_{2}$ : Post-test control group

$\mathrm{X}$ : Writing recount text by using photographs

Y : Writing recount text by using conventional media

\section{B. Research Variables}

This research was an experimental research. It has two variables that become the keywords of the study. They consist of:

Independent : Photograph is used in teaching variable writing recount text.

Dependent : Writing ability of the students variable who involved in this research.

\section{Research Instruments}

Creswell (2008: 167) argues that an instrument is a tool for measuring, observing, or documenting quantitative data. Modifying an instrument means locating an existing instrument, obtaining permission to change it, and making changes in it to fit your requirements.

The instrument that was used to collect the data was English writing test. The kind of English writing test was an essay test. The students' writing ability was measured from Jacob's scoring test: content, organization, vocabulary, language use and mechanics. Weigle (2009: 116) asserts that there are five indicators to consider in writing test: content, organization, vocabulary, language use, and mechanics.

\section{Hypothesis}

Hypothesis was the writer's prediction towards the result that would be gained in this research. Iqbal (2002: 50) states that hypothesis is the temporary answer toward the problem of the study that still has weak truth, so it must be examined empirically.

The hypothesis of this research is there is a significant difference of writing ability between the students taught by using photographs and those who taught by using conventional media of the experiment group and the control group of students of Senior High School Kalimantan Tengah. 


\section{RESEARCH FINDINGS}

\section{A. Descriptive Statistics}

This research was an experimental research, which has function to find out the effect of using photographs to writing ability. The effect of using photographs can be seen from the gained scores of the subject of the research. Therefore the conclusion of this research was taken by comparing the mean of the gained scores of the students who were taught by using photographs with the gained scores of the students who were taught by using conventional media.

The tenth grade students of Senior High School 1 Karau Kuala Kalimantan Tengah consisted of four classes. Two classes only were as the sample. They were class X-D containing twenty three students performs as control group, and class X-C containing twenty three students perform as experiment group. In the descriptive statistics, it described and explained the data on score of the students' test result, those taught by using photographs (experiment group) and that taught by using conventional media (control group), and then compared both variables in order to know which one was the higher. The result of the test can be presented into mean, standard deviation, and the range of minimum and maximum scores of each variable.

\section{Pre-test}

Pretest was the first test by giving to the students after observing the English teaching learning process in the class. The pre-test was conducted for both experiment group and control group. The pre-test was administered on February 3, 2014 for experiment group and on February 5, 2014 for control group.

In the pre-test the students was asked to write the recount text without using photograph. The pre-test was about one and a half hours. Every student was asked one question in the form of essay test. First, stimulating the students' background knowledge about recount text. Then, introducing the topic or the material to learn and asked the students to write recount text based on the topic. In this stage the students wrote the writing recount text without photograph to know the students' ability in writing before the treatment.

\section{a. Experiment Group Students' Pretest Score}

The total numbers of the students who belong to experiment group were twenty three students. The highest score of pre-test in experiment group was 70 and the lowest score was 34. The mean score of pre-test was 51.17 and the standard deviation was 8.299. The experiment group students' pre-test score. There was a student who got score 67-74. There were two students who got score 59-66. There were twelve students who got score 50-58. There were seven students who got score 42-49. There was a student who got score 34-41.

The students also classified into master and fail category based on the Minimum Criteria for Completeness of English Subject of the tenth grade students of Senior High School Kalimantan. There were three students (13.04\%) who belonged to master category and there were twenty students $(86.96 \%)$ who belonged to fail category in the pre-test of experiment group.

\section{b. Control Group Students' Pre-test Score}

The total numbers of the students who belong to control group were twenty three students. The highest score of pretest in control group was 75 and the lowest score was 36. The mean score of pre-test was 54.61 and the standard deviation was 9.586 .

The control group students' pre-test score. There were three students who got score 67.5-75.5. There were three students who got score 59.5-67.5. There were six students who got score 51.5-60.5. There were nine students who got score 43.551.5. There were two students who got score 35.5-43.5.

The students also classified into master and fail category based on the Minimum Criteria for Completeness of English Subject of the tenth grade students of Senior High School Kalimantan Tengah. There were five students $(21.74 \%)$ who belonged to master category and there were eighty students (78.26\%) who belonged to fail category in the pre-test of Control group.

\section{Pre-test}

This research consisted of eight meetings for each group. The first and last meetings were for pre-test and post-test and six meetings were for treatment. It took from February 3, 2014 to February 28, 2014.

In the treatment was explained about the meaning of recount text, the language features, how to make a good story of recount text and also explained about how to arrange the sentence in simple past tense. Teaching writing recount text by using photograph was for experiment group and teaching writing recount text by using conventional media was for the control group. The test only used one type of writing test in the form of essay test in the pre-test and post-test while in the treatment was used objective test in the form of filling in the blank task and changing the sentences into positive, negative and interrogative sentences and subjective test in the form of essay test.

\section{Post-test}

Post-test as the last test was given after treatment. The test was similar with the pre-test. The post-test would be done after the treatment given to the students to practice a writing recount text by using photographs in the class.

The post-test was conducted on February 28, 2014 for experiment group (Class X-C) and on February 27, 2014 for control group (class X-D). The test was administered by giving the students a task to write a recount text. The pre-test was about one and a half hours. It was conducted by giving the students a writing recount test based on the students' personal photograph. Every student was asked one question in the form of essay test.

The post test was done to know whether there was a significant difference between experiment group those who taught by using photographs and control group those who taught by using conventional media.

\section{b. Control Group Students' Post test Score}

The result of post-test in control class, the mean was 60.43 with standard deviation was 9.080. Meanwhile the highest 
score which reached by the students in control group was 80 and the minimum score was 48 .

The control group students' posttest score. There was a student who got score 76-82. There were four students who got score 69.-75. There were five students who got score 6268. There were five students who got score 55-61. There were eight students who got score 48-54.

The students also classified into master and fail category based on the Minimum Criteria for Completeness of English subject at the tenth-grade students of Senior High School Kalimantan Tengah. There were ten students (43.48\%) who belonged to master category and there were thirty students $(56.52 \%)$ who belonged to fail category in the post-test of the control group.

\section{B. Inferential Statistics}

There were two requirements that should be fulfilled before analyzing the data: normality and homogenous testing. The following discussion gives the explanation about the normality and homogenous testing.

\section{Normality Testing}

The normality testing conducted using Shapiro-Wilk analysis at 5\% significant level. The calculation of normality testing showed that the analysis was normal.

The data of pre-test was normal. The reason was the value of the probability (significance) was higher than 0.05 . It can be stated that $0.260>0.05$ for the experiment group and 0.436 $>0.05$ for the control group. Therefore, it can be stated that the distribution of the gained score in the pre-test was normal.

The data of post-test was normal. The result showed that the value of the probability (significance) was higher than 0.05 . $0.776>0.05$ for the experiment group and $0.115>0.05$ for the control group. It means that the distribution of the gained score in the post-test was normal.

\section{Homogenous Testing}

Homogenous testing utilized to analyze if the data was homogeneous or not. Homogenous testing was accounted by using SPSS program.

The significance of the students' writing ability in the pretest indicated in the coefficient of homogenous. The test can be said homogenous if the probability (significance) was higher than 0.05 . The result can be concluded that the data were homogenous, because the value of the probability (significance) was $0.326(0.326>0.05)$. Therefore, the variance of the two groups in the pre-test was homogenous and the sample has the same variance, so the data met the requirement of a research analysis.

In the post-test score calculation, the significance of the students' writing ability in the post-test indicated in the coefficient of homogenous. The test can be said homogenous if the probability (significance) was higher than 0.05. Based on the calculation of the post-test score in the table above, the result can be concluded that the data were homogenous because the value of the probability (significance) was 0.960 $(0.960>0.05)$. Therefore, the variance of the two groups in post-test was homogenous and the sample has the same variance, so the data met the requirement for a research analysis.

\section{Hypothesis Testing}

The hypothesis testing aimed at revealing whether or not there was a significant difference between students' writing ability that taught by using photographs and taught by using conventional media of the tenth-grade students of Senior High School in Kalimantan Tengah. The level significant was set on 0.05 or $5 \%$.

From the result of data description presented above, it can be concluded that the mean between the experimental group and the control group were different. The mean of pre-test and post-test of the control group were 54.61 and 60.43 . The mean of pre-test and post-test of the experiment group were 51.17 and 75.43. It showed that the mean of the experiment group was higher than the mean of control group. It means that there was a significant difference of writing ability between the students taught by using photographs and those who taught by using conventional media of the experiment group and the control group of the tenth grade students of Senior High School in Kalimantan Tengah.

To prove whether or not there was a significant difference of writing ability between students taught by using photographs and those taught by using conventional media, the hypothesis testing is done. The hypothesis was accepted if the value of the significance is smaller than 0.05 or the value of t-observe is higher than t-table.

The result showed that the value of significance was 0.201 higher than 0.05 or t-observe was 1.299 lower than t-table was 2.02. It means that hypothesis was rejected. Therefore, it can be concluded that the students' writing ability between the experimental group and control group was no significant difference in the pre-test.

This research also showed that the value of the significance was 0.000 smaller than 0.05 or t-observe was 5.513 higher than t-table was 2.02. It means that hypothesis was accepted. Therefore, it can be concluded that the students' writing ability between the experimental group and control group was significantly difference in the post-test.

\section{Discussion}

1. The writing ability of the tenth-grade students of Senior High School Kalimantan Tengah taught by using photographs.

The score of the writing ability of the tenth-grade students of Senior High School Kalimantan Tengah taught by using photographs after the treatment was higher than the score of the students' writing ability before treatment. Before treatment the mean score of experiment group was 51.17 and after the treatment the mean score of the experiment group was 75.43 the minimal score of the experiment group was 34 and the maximum score of the experiment group was 70 after the treatment the minimal score was 60 and the maximum score was 94 the mean of the score of the test was 75.43 while the standard deviation was 9.370 . 
The students`writing ability taught by using photographs was very good. It means that the photographs arise the student ' motivation to get ideas, taught, feeling, and express them into written. There was increased scored in writing ability after the students got the treatment by using photographs. From the explanation above, it indicated that lesson by using photographs in teaching writing could improve the students to write and could raise the students' motivation in learning.

The findings showed that in the experiment group (using photographs), there were 20 students $(86.96 \%)$ who belonged to master category and there were 3 students $(13.04 \%)$ who belonged to fail category in the writing test. Those scores were compared with the gained scores of the control group. From the findings, it can be seen that there were 10 students $(43.48 \%)$ who belonged to master category and there were 13 students (56. 52\%) who belonged to fail category. It can be concluded that the number of the students who belonged to the master category in the experiment group was more than that in the control group.

The result of calculation showed that photographs gave a significant effect toward the students' writing ability. The students who used photographs got higher scores than the students who did not. The psychological effect of using photograph was that the students' motivation was increased because they felt happy learning the material. Finally, the students would get higher scores. As what has been stated in chapter II, there are some advantages of using photographs in teaching-learning process.

Wright (1989:2) states that media are anything that can be used to make learning run smoothly, increase students' interest and motivation and sense of the content of the language. Photograph or real picture is one of visual aids that can be used in teaching and learning English. It creates the situation for learning classes and interesting. Kreidler (1968: 41) stated that the ultimate of writing is to give the students the opportunity to express their own ideas clearly, using pattern they have learned.

By photograph, learners can show people, places, and things from areas outside their own experiences (Gerlach and Ely, 2003: 273). Photograph as one type of picture can present social context in classroom in which people and places are put together in certain relation creating events that can trigger students' imagination. Hopefully, after visual literary is boosted by the present of photograph, students can also improve their literacy, especially writing recount context. Photograph that can show areas outside one experience enable learners to be able to explain anything that they can perceive from the photograph, even something new for them. Photograph visual detail makes it possible to study subjects which would otherwise be impossible (Gerlach and Ely, 2003: 277).

According to Raimes (2002: 27-28) a photograph is available resource as it provides: (1) Shares experience in the classroom, (2) a need common language form re use in the classroom, (3) a variety of tasks, and (4) a focus of interest for students.
Photographs are the original picture and a visual media that sure useful in process writing recount text. Photograph usually captures past events, and photograph surely can help students remember details about people, places and events. In short they can be powerful sources of text. Besides, a photograph is worth a thousand words because one picture can tell students something, even have sequences of story behind it. It was appropriate with writing recount text because recount text use to reconstruct past experiences by retelling events and incident in order in which they have occurred. So that they write confidently and they can produce a better writing than write without using photographs.

\section{The writing ability of the tenth grade 2. Students of Senior High School Kalimantan Tengah taught by using conventional media.}

The description of writing ability of the students who was taught by using conventional media is discussed in this part. After conducting the instrument, the data or the result of the test was conducted.

The result of the control group showed that there was no significant increase about the mean score of the students' writing ability. The mean score in the pre-test was 54.61 and the mean score in the post-test was 60.43 the minimum score in the pre-test was 36 and the maximum score in the pre-test was 75 the minimum score in the post-test was 48 and the maximum score was 80 .

In the control group, there was no a significant increase the mean score of the students' writing ability. The students in control group sometimes forgot the vocabulary, grammar, content, and mechanic. Most of the students found difficulties in developing paragraph and finding appropriate vocabulary. It means that they were not interested in the lesson because of the method that made them felt bored.

\section{The significant difference of writing ability between the students taught by using photographs and those taught by using conventional media of the experiment group and the control group.}

The result of calculation showed that photographs gave a significant effect toward the students' writing ability. It can be seen from the result of t-test showing that the value of significance $(0.000)$ was lower than 0.05 . If the significance (0.000) was smaller than 0.05 , or t-observe (5.513) was higher than t-table (2.02), It means that there was a significant difference in teaching writing by using photographs and teaching writing by using conventional media.

By using photograph of teaching writing recount text, the students will enjoy the following English class. They will be easy to understand the lesson, it is expected that using photograph is interesting and effective to raise students' motivation in learning writing recount texts. It can be seen that the gained score of the experiment group and control group in the post-test. The mean score of the experiment group was 75.43 was higher than that of control group was 60.43 , in the other word, it can be said that there was a 
significant difference of writing ability between the students taught by using photographs and those who taught by using conventional media of the experiment group and the control.

\section{CONCLUSIONS}

\section{Conclusion}

This experiment research took the tenth-grade students of Senior High School Karau Kuala Kalimantan Tengah as the research object, to find out the effect of using photographs. However, based on the research findings and the discussion in chapter IV, the result of this research can be summarized as follows:

There was a significant difference between the students taught by using photographs and taught by using conventional media. The mean of experiment group in the post-test was 75.43 , the df was 44 , and the value of the significance was 0.000 . If the value of the significance $(0.000)$ was smaller than 0.05 , or t-observe (5.513) was higher than t-table (2.02), the alternative hypothesis was accepted. It means that there was a significant difference of writing ability between the students taught by using photographs and those who taught by using conventional media of the experiment group and the control group.

The result of the analysis of the writing recount text ability of the students taught by using photographs (experiment group) showed that the mean score of the pre-test was 51.17. And the mean score of post-test was 75.43. From the mean scores of the pre-test and post-test the experiment group, it can be seen that there was a significant progress from pre-test to the posttest. Photographs gave a significant effect toward the students' writing ability. Photographs arise the students' motivation to get ideas, taught, feeling, and express them into written. The students who used photographs got higher scores than the students who did not. The psychological effect of using photograph was that the students' motivation was increased because they felt happy learning the material.

The result of the analysis of the writing ability of the students taught by using conventional media (Control group) showed that the mean score of the pre-test was 54.61. And the mean score of post-test was 60.43. From the mean scores of the pre-test and post-test the control group, it can be seen that there was progress but not significant progress than the mean score of the pre-test and post-test in the experiment group. The students in control group sometimes forgot the vocabulary, grammar, content, and mechanic. Most of the students found difficulties in developing paragraph and finding appropriate vocabulary. It means that they were not interested in the lesson because of the method that made them felt bored.

\section{B. Suggestions}

There are some suggestions that are addressed to the other researchers, English teacher, and students as follows:

\section{Next Researchers}

The next researchers can make this study as their reference to conduct other researcher on the same field. They are also expected to be able to cover the limitation about this; they can conduct a research with the same media but in different genres. The next researchers can prepare everything as good as possible in doing research and can follow up this research.

\section{English Teachers}

English teachers can use photographs in teaching writing. The teachers should give various attractive and interesting media to the students in teaching learning process, especially in teaching writing activity, so that the students will not bored.

\section{Students}

a. Students should be given motivation to read any recount text to increase their understanding about recount text.

b. Students should be given more time to analyze some recount texts as models to write.

c. The students encourage themselves to learn English especially writing a recount text.

\section{REFERENCES}

Ann Kipfer, Barbara. 2001. Random House Webster's College Dictionary. New York: Random House.

Arsyad, Azhar. 1997. Media Pembelajaran. Jakarta: Raja grafindo Persada.

Arikunto, Suharsimi. 2000. Manajemen Penelitian, Jakarta:PT. Rineka Citra. Rineka Cipta.

2005. Manajemen Penelitian. Jakarta:

Asnawir and Usman. 2002. Media Pembelajaran. Jakarta:Ciputat Press.

Brown, H. D. 1987. Principles of Language Learning and Teaching. Englewood Cliffs, NJ: Prentice Hall. 2007. Teaching by Principles: An Interactive Approach to Language Pedagogy 3rd edition. San Francisco: State University.

Byrne, Donn. 1980. Teaching Writing Skills. London: Harlow, Essex: Longman.

Campbell, T. Donald and Julian, C. Stanley. 1966. Experimental and Quasi-Experimental Designs for Research. Boston:Houghton Mifflin Company.

Creswell, J.W. 2008. Education Research. Planning, Conducting, and Evaluting Quantitative and Qualitative Research. New Jersey: Merrill Prentice Hall.

Dale, E Ann Kipfer, Barbara. 2001. Random House Webster's College Dictionary. New York: Random House.

Arsyad, Azhar. 1997. Media Pembelajaran. Jakarta: Raja grafindo Persada.

Arikunto, Suharsimi. 2000. Manajemen Penelitian, Jakarta:PT. Rineka Citra.

Rineka Cipta.

2005. Manajemen Penelitian. Jakarta:

Asnawir and Usman. 2002. Media Pembelajaran. Jakarta:Ciputat Press. 
Brown, H. D. 1987. Principles of Language Learning and Teaching. Englewood Cliffs, NJ: Prentice Hall. 2007. Teaching by Principles: An Interactive Approach to Language Pedagogy 3rd edition. San Francisco: State University.

Byrne, Donn. 1980. Teaching Writing Skills. London: Harlow, Essex: Longman.

Campbell, T. Donald and Julian, C. Stanley. 1966. Experimental and Quasi-Experimental Designs for Research. Boston:Houghton Mifflin Company.

Creswell, J.W. 2008. Education Research. Planning, Conducting, and Evaluting Quantitative and Qualitative Research. New Jersey: Merrill Prentice Hall.

Dale, E. 1969. Audio Visual Methods in Teaching. New York: Dryden Press.

Derewianka, Beverly .1990. Exploring how texts work. University of Virginia: Primary English Teaching Association.

Dulla, Heidi et al. 1982. Language Two. New York: Oxford University Press.

Echols, John. 1975. Kamus Inggris Indonesia. Jakarta: Gramedia.

Fauziati, Endang. 2002. Teaching English as a foreign language. Surakarta: Muhammadiyah University Press.

Gerlach S Vernon and Elly P Donal. 1980. Teaching and Media a Systematic Approach. New Jersey: Prentice Hall.

Goodwyn, Andrew. 1992. English Teaching and Media Educational. Buckingham: Open University Press.

Harmer, Jeremy. 2007. How to Teach English. China: Pearson Longma.

. 2001. The Practice of English Language Teaching. London: Pearson Education.

Hasan, M.Iqbal. 2002. Pokok-pokok Materi Metodologi Penelitian dan Aplikasinya, Jakarta: Ghalia Indonesia.

Hatch, Evelyn and Hossein Farhady, 1982. Research Design and Statistic for Applied Linguistics. New York: Newbuty House Publisher. Inc.

Heaton, JB. 1989. Writing English Language Tests. New work: Longman Group.

Heffernan, James. 2006. Cultivating Picturacy. Visual art and verbal Intervention. Texas: Baylor University Press.

Heinrich R. Molenda M. Russel J. D, \& Smatlido. 2002. Instructional media and Technolnogies for learning (7th Ed). New Jersey: Pearson Education, Upper Saddble River.

Hornby. 1995. Oxford Advanced Learner's Dictionary. Oxford:University press.

Hughes, A. 2005. Testing for Language Teachers, Second Edition. United Kingdom: Cambridge University Press.

Hyland, Ken, 2004. genre and Second Language Writing, The United State of America: The University of Michigan Press.

Kemp, J. 1977. Instructional Design: A plan for unit and course development. Belmont: Fearon-Pitman Pub.
Klasek, C. B. 1972. International Media in Modern School. London: Macmillan Press.

Kreidler, Carol. 1965. Visual Aids for Teaching English to the Speakers of other Language Washington D.C. Center for Applied Linguistics.

Latuheru, J. D. 1988. Media Pembelajaran dalan Proses Belajar Mengajar Masa Kini. Jakarta: P3G.

Margono. 1996. Metodologi Penelitian Pendidikan. Semarang:Rineka Cipta.

Neelands. 1994. Writing in Imagined Contexts, Toronto, and Research Services Toronto Board of Education.

Nirwanto, Rahrmadi. An Enrichment Material for Writing IV. Palangka Raya.

Oshima and Hogue. 1991. Writing Academic English. USA: Addison-Wesley Publishing Company, Inc.

Raimes, A. 2002. Techniques in Teaching Writing. New York: Oxford University Press.

Roediger, H. L., III, \& Marsh, E. J. 2005. The positive and negative consequences of multiple-choice testing. Journal of Experimental Psychology: Learning, Memory, \& Cognition.

Sadiman, S Arief et.al. 1996. Media Pendidikan: pengertian, pengembangan, dan pemanfaatanya. Jakarta: Ciputat Pers.

Scott, Clice. 1999. The Spoken Image: Photography and Language. London: Reaktion Books.

Sudjana \& Rivai. 1992. Media Pengajaran Bahasa. Yogyakarta: Andi Offset.

Sulaeman, D. 1988. Teknologi/Metodologi Pengajaran. Jakarta: Depdikbud.

Surakhmad.1982. Pengantar Penelitian Ilmiah Dasar Metode dan Tehnik. Bandung: Tarsito.

Toendan, Wido E. 2006. Educational Research Method, Palangka Raya:Unpublised.

Wright, Andrew. 1989. Pictures for Language Learning (5th ed.). Australia: Cambridge University Press.

Yuswotomo. 1991. Alat Bantu Mengajar Bahasa Inggris. Malang: Proyek OPF IKIP Malang. 